naselennia ta vykorystannia resursiv okhorony zdorovia $v$ Ukraini za 2013-2014 roky. [Indicators of Public Health and the Use of Health Care Resources in Ukraine for 2013-2014]. Kyiv ; 2015 : 328 p. (in Ukrainian).

6. Slabkyi H.O., Dudnyk S.V., Dudina O.O., Haborets S.R. Zahalna kharakterystyka stanu zdoroviia naselennia Ukrainy [General Characteristics of the Health Status of the Population of Ukraine]. Rehionalni systemy okhorony zdoroviia Ukrainy 2014 rik. Kyiv ; 2015 (I) : 6 -26 (in Ukrainian).

7. Herasymenko H.V. Demohrafiia ta sotsialna ekonomika. 2017 ; 1 (29) : 11-23 (in Ukrainian).

8. Chepelevska L.A. and Orda O.M. Ukraina. Zdorovia natsii. 2011; 2 : 68-73

(in Ukrainian).

9. Shchorichna dopovid pro stan zdorovia naselennia, sanitarno-epidemichnu sytuatsiiu ta rezultaty diialnosti systemy okhorony zdorovia Ukrainy. 2016 rik [Annual Report on the State of Health of the Population, Sanitary and Epidemiological Situation and Results of the Health Care System of Ukraine. 2016 year]. Ministry of Health of Ukrainy ; DU «UISD MOZ Ukrainy». Kyiv ; 2017 : 516 p. (in Ukrainian).

10. Early Years, Family and Education Task Group: Report. European Review of Social Determinants and the Health Divide in the WHO European Region / B. Jensen, C. Currie, A. Dyson, N. Eisenstadt, E. Melhuish (editors). Copenhagen : WHO Regional Office for Europe ; 2013. URL : http://www. euro.who.int/data/assets/ pdf file/0006/236193/Earlyyears, -family-and-educationtask-group-report.pdf

11. Improving the Lives of Children and Young People: Case Studies from Europe. Vol. 1. Early Years. Copenhagen : WHO Regional Office for Europe ; 2013. URL : http:// www. euro. who.int/en/publications/abstracts/improving-thelives-of-children-and-youngpeople-case-studies-fromeurope--volume-1. -early-years.

12. World Health Statistics 2013. Part III. Global Health Indicators. Geneva : WHO ; 2015 : 139 p.

13. World Health Statistics 2015. Part II. Global Health Indicators. Geneva : WHO ; 2015 : $125-135$.

Надійшло до редакції 24.05.2018

\section{EXIERNAL CAUSES OF MORTALITY IN UKRAINE: STANDARDIZED RISKS AND LOST PROFIT}

Kartashova S.S., Kaneva T.V., Omelchenko E.M., Polka O.O.

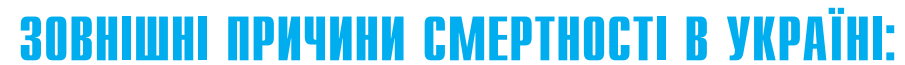
СТАНДАРТИЗОВАНІ РИЗИКИ ТА УПУЩЕНА ВИГОДА
1КАРТАШОВА C.C., 1 KAHEBA T.B., 2ОМЕЛЬЧЕНКО Е.М., 2ПОЛЬКА 0.0.

${ }^{1}$ Київський національний торгово-економічний університет, м. Київ, 2ДУ «Інститут громадського здоров'я ім. О.М. Марзєєва НАМН України», м. Київ УДК 614.1/2: $314.18: 314.4$

Ключові слова: смертність, зовнішні причини смерті, втрачені роки потенційного життя, стандартизована структура, відносний ризик, упущена вигода. івень смертності у різних статево-вікових групах населення істотно відрізняється і залежить від сполученої дії чинників, серед яких виділяють ендогенні фактори, пов'язані з природним старінням організму, особливостями його фізіології, спадковості, психотипу, та екзогенні, що зумовлені впливом зовнішнього середовища, тобто соціально-економічною та екологічною ситуацією, рівнем розвитку охорони здоров'я, осо-
ВНЕШНИЕ ПРИЧИНЫ СМЕРТНОСТИ В УКРАИНЕ:

СТАНДАРТИЗИРОВАННЫЕ РИСКИ И УПУЩЕННАЯ ВЫГОДА

${ }^{1}$ Карташова С. С., ${ }^{1}$ Канева Т.В., 2 Омельченко Э.М., 2 Полька Е.А.

1 Киевский национальный торгово-экономический университет, г. Киев, 2 ГУ «Институт общественного здоровья им. А.Н. Марзеева НАMН Украины», г. Киев

По уровню смертности от внешних причин Украина более чем в два раза опережает страны Европейского Союза. Роль внешних причин в нашем государстве недооценивается и недостаточно учитывается при определении приоритетов политики, направленной на снижение смертности и увеличение продолжительности жизни.

Цель исследования заключалась в определении демографических и социально-экономических потерь государства от внешних причин смерти (МКБ-10: V01-Y98), в том числе и по их отдельным нозологиям (МКБ-10: X45, V01-V99, Х60-Х84).

Материалы и методы. В качестве источников первичной информации использованы данные системы национальных счетов, форм государственной статистической отчетности: ф. С-8 «Распределение умерших по полу, возрастным группам и причинам смерти», ф. A-1 "Общие итоги естественного движения» и информация

Министерства финансов Украины о значении учетной ставки НБУ. Результаты. Согласно классической структуре смертности внешние причины занимают третье ранговое место после болезней системы кровообращения и новообразований, в то время как по показателю ПГПЖ - второе, при этом их удельный вес увеличился в 3,7 раза. Последнее обусловлено тем, что средний возраст умерших от внешних причин в 1,9 раза меньше, чем у тех, кто умер от болезней системы кровообращения. Среди всех внешних причин смерти особое внимание следует уделить ДТП, случайным отравлениям и действию алкоголя, суицидам. Их удельный вес среди внешних причин составляет $50 \%$. При анализе и оценке структурных сдвигов в классе внешних причин обнаружено увеличение удельного веса суицидов и уженского (на $(42,2 \pm 1,2) \%)$, и у мужского (на $(37,1 \pm 0,8) \%$ ) населения за 2009-2016 годы. Проведенное ранжирование областей государства по величине относительного риска определило территории повышенного риска по всем внешним причинам смерти и по отдельным нозологиям (ДТП, суициды, случайные отравления и действие алкоголя). Снижение риска смерти от этих причин до среднегосударственного сохранило бы жизни около 7 тысяч человек, при этом только за 2015-2016 годы упущенная выгода государства превысила бы 14 млрд. гривен. Ключевые слова: смертность, внешние причины, потерянные годы потенциальной жизни, стандартизированная структура, относительный риск, упущенная выгода.

(ㄷ Карташова С.С., Канева Т.В., Омельченко Е.М. Полька О.О. СТАТТЯ, 2018. 
Таке очікування є небезпечним. Хоча зовнішні причини смерті, разом з багатьма іншими причинами, існували ність їх вивчення зумовлена тим, що у багатьох країнах, до яких, безумовно, належить і Україна, висока смертність саме з причин цього класу $€$ однією 3 головних перешкод на шляху подовження тривалості життя. Роль зовнішніх причин смерті у нашій державі недооцінюється і недостатньо враховується під час визначення пріоритетів політики, спрямованої на зниження смертності i, як наслідок, подовженню тривалості життя.

Згідно з даними Державної служби статистики [4, 5] за 2005-2016 роки в Україні 3 зовнішніх причин загинуло 586 тис. осіб, тобто у 3,5 рази більше, ніж через інфекційні хвороби (168 тис. осіб). Проте боротьба з зовнішніми причинами у державі ніколи не декзавжди, нинішня ж актуаль-

ларувалася як пріоритетна, на відміну, наприклад, від профілактичної вакцинації дитячого населення.

У зв'язку з вищевикладеним мета роботи полягала $\mathrm{y}$ визначенні демографічних та соціально-економічних втрат держави через зовнішні причини смерті (MKX-10: V01Y98) та їх окремі нозології (MKX-10: X45, V01-V99, X60X84).

Матеріали та методи. За джерела первинної інформації було використано демографічні щорічники, дані системи національних рахунків та статево-вікової структури постійного населення, експрес-випусків Державної служби статистики України, форми державної статистичної звітності, а саме: ф. С-8 «Розподіл померлих за статтю, віковими групами і причинами смерті», А-1 «Загальні підсумки природного руху» та інформація Міністерства фінансів щодо значення облікової впливами. Вони можуть навмисними (вбивства і самогубства) або ненавмисними (нещасні випадки, пов'язані з транспортним рухом або викликані вогнем; утоплення; отруєння; падіння), виділяють також пошкодження з невизначеними намірами.

Зовнішні причини належать до того класу причин смерті, які у сучасному суспільстві можна усунути. Більш того, зовнішні причини не можна недооцінювати ще й тому, що вони можуть призвести не тільки до смерті, але й до інвалідності. За оцінками В003, на кожен випадок смерті в Європейському регіоні припадає 32 госпіталізації, 300 звернень у відділення невідкладної допомоги та близько 1000 звернень по допомогу до лікарів загального профілю або спроб самолікування [2].

За рівнем смертності через зовнішні причини Україна більш ніж удвічі випереджає країни Європейського Союзу (рис. 1) [3].

При збереженні у подальшому темпів зниження (TZ), що протягом 2009-2015 років складали 2,84 на 105, відповідного населення, нинішнього рівня ЄС ми зможемо досягти не раніше 2030 року.

\section{Стандартизовані показники смертності через зовнішні причини смерті (MKX-10: V01-Y98) на $10^{5}$ нас., 2005-2015 роки}

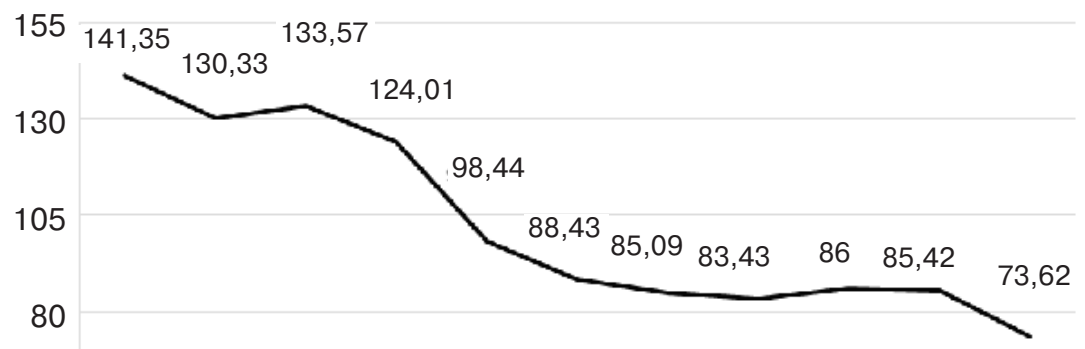

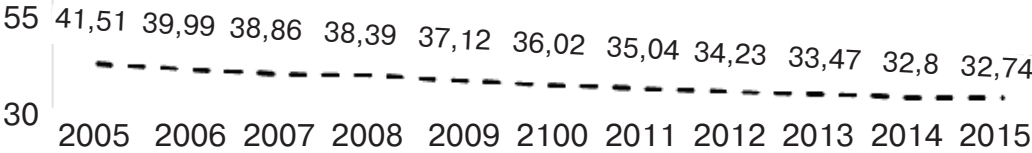

Рисунок 2

Структура смертності за причинами: класична та за показником ВРПЖ, Україна, 2015-2016 роки
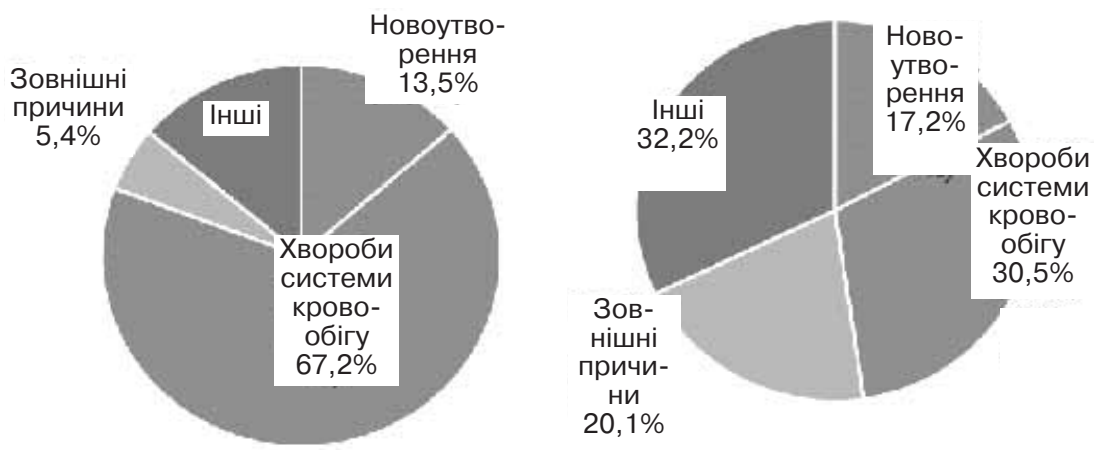
EXTERNAL CAUSES OF MORTALITY IN UKRAINE: STANDARDIZED RISKS AND LOST PROFIT

${ }^{1}$ Kartashova S.S., ${ }^{1}$ Kaneva T.V.,

2Omelchenko E.M., 2 Polka O.O.

${ }^{1}$ Kyiv National University of Trade and Economics, Kyiv, Ukraine

2SI «O.M. Marzeyev Institute for Public Health, National Academy of Medical Sciences of Ukraine", Kyiv, Ukraine

Background: By the level of mortality of the external causes, Ukraine passes ahead of the countries of the European Union more than twice. The role of the external causes in our state is underestimated and insufficiently taken into account in the determination of the priorities of the policy directed to the reduction of the mortality and the increase of lifetime.

Objective: We determined the demographic and socio-economic losses of the state through external causes of death (ICD-10: V01-Y98), including their individual nosologies (ICD-10: X45, V01-V99, X60-X84).

Materials and methods: The data of the system of national accounts, forms of state statistical records: f. P-8 «Distribution of the deceased by sex, age groups, and causes of death» and $f$. A-1 «General results of natural movement» and on the significance of the NBU discount rate of the Ministry of Finance were used as the sources of primary information.

Results and conclusions: According to the classical structure of mortality, the external causes occu- py the third ranked position after diseases of circulatory system and neoplasms while by the parameter of the YPLL (Years of Potential Life Lost) - the second one, and at this time their share increased 3.7 times. The latter is because the average age of the dead of the external causes is smaller by a factor of 1.9 than those who died of the circulatory system diseases.

Among all external causes of death, special attention should be given to the accidents, the accidental poisoning, and the effects of alcohol, suicides: their share among external causes is $\approx 50 \%$. At the analysis and assessment of the structural changes in the class of the external causes, an increase in the share of suicides in 2009-2016 was detected among both the female (by (42.2 \pm 1.2$) \%$ ) and the male one (by $(37.1 \pm 0.8) \%$ ) population. Performed ranking of the regions of the state in terms of relative risk established the territories of increased risk both for all external causes of death and individual nosologies (accidents, suicides, accidental poisoning and the effects of alcohol). Reduction of the risk of death of those causes to the average state would save about 7 thousands persons while the lost profit of the state would exceed 14 billions UAH only in 2015-2016.

Keywords: mortality, external causes of death, lost years of potential life, standardized structure, relative risk, lost profit. ставки НБУ за 2005-2016 роки.

При виконанні роботи застосовано системний підхід, який базується на поєднанні методів соціально-економічної статистики, медико-демографічних, актуарної математики та теорії ймовірностей.

Результати та їх обговорення. Державна статистична звітність щодо захворюваності та смертності населення починаючи з 2005 року подається згідно з міжнародною класифікацією хвороб десятого перегляду (MKX10). Це дозволяє проводити коректні співставлення та порівняння стандартизованих показників смертності як за класами хвороб, так і за окремими нозологіями на міжнародному рівні.

В Україні зовнішні причини смерті посідають третє рангове місце (класична структура смертності) і суттєво впливають не тільки на очікувану тривалість життя, а й взагалі на стан громадського здоров'я.

Протягом останнього десятиріччя смертність з цих причин у державі демонструє певні позитивні зміни: відбулося суттєве зменшення стандартизованого показни- ка (прямий метод), розрахованого на $10^{5}$ відповідного населення, з 141,35 до 73,62, при цьому середньорічні темпи зниження склали $\mathrm{TZ}_{2005-2010}=6,87\left(\mathrm{TZ}_{2005-2009}=\right.$ 9,21, $\left.\mathrm{TZ}_{2009-2015}=2,84\right)$.

Загалом за два суміжні роки (2015-2016 стандартизований показник смертно-

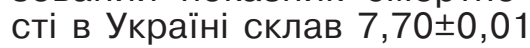
на $10^{5}$ відповідного на-

селення. Перші п'ять рангових місць посідають Житомирська та Дніпропетровська області $(9,99 \pm 0,05)$, Херсонська $(9,97 \pm 0,05)$, Кіровоградська $(9,93 \pm 0,06)$, Чернігівська $(9,47 \pm 0,06)$. Найліпша ситуація спостерігалася у м. Києві $(4,97 \pm 0,02)$, Івано-Франківській $(5,24 \pm 0,03)$, Тернопільській $(5,48 \pm 0,04)$ та Львівській $(6,06 \pm 0,03)$ областях

Таблиця 1

Питома вага окремих причин смерті (нозологій) за показником ВРПЖ у класі усіх зовнішніх причин, Україна, 2015-2016 роки

\begin{tabular}{|c|c|c|c|}
\hline \multirow{2}{*}{$\begin{array}{c}\text { Причина за MKX-10 у класі зовнішніх } \\
\text { причин смерті: V01-Y98 }\end{array}$} & \multicolumn{3}{|c|}{ Стать } \\
\hline & чоловіки & жінки & $\begin{array}{l}\text { обидві } \\
\text { статі }\end{array}$ \\
\hline Транспортні нещасні випадки:V01-V99 & 16,52 & 20,92 & 17,27 \\
\hline Падіння: W00-W19 & 4,19 & 3,22 & 4,03 \\
\hline Утоплення та занурення у воду: W65-W74 & 6,89 & 4,80 & 6,54 \\
\hline $\begin{array}{l}\text { Нещасні випадки, спричинені дією диму, } \\
\text { вогню та полум'я: Х00-Х09 }\end{array}$ & 2,37 & 2,75 & 2,44 \\
\hline Випадкове отруєння та дія алкоголю: Х45 & 8,66 & 7,77 & 8,50 \\
\hline $\begin{array}{l}\text { Випадкове отруєння, спричинене іншими } \\
\text { отруйними речовинами: X40-X44, X46-X49 }\end{array}$ & 3,79 & 4,31 & 3,88 \\
\hline Навмисне самоушкодження: Х60-Х84 & 21,62 & 19,20 & 21,21 \\
\hline $\begin{array}{l}\text { Наслідки нападу з метою убивства чи } \\
\text { нанесення ушкодження: Х85-Ү09 }\end{array}$ & 5,84 & 9,35 & 6,45 \\
\hline $\begin{array}{l}\text { Інші зовнішні причини смерті: W20-W64, } \\
\text { W75-W99, X10-Х39, X50-Х59, Y10-Y89 }\end{array}$ & 30,11 & 27,67 & 29,69 \\
\hline
\end{tabular}


3 класичною (рис. 2) питома вага хвороб системи кровообігу зменшується у 2,2 рази, але збільшується у 3,7 рази для зовнішніх причин смерті.

Останніми роками 3 усіх зовнішніх причин на офіційному рівні позначено в якості головної тільки дорожньотранспортний травматизм. Смертність через напади, самоушкодження, алкогольні отруєння та інші зовнішні причини не знаходить нині належної уваги.

Структуру смертності з зовнішніх причин за показниками ВРПЖ подано у таблиці 1. При ранжуванні іï за вказаними причинами суттєвих відмінностей від класичної структури не виявлено.

Для подальшої науково коректної характеристики структури смертності з зовнішніх причин та її можливих структурних зрушень проведено стратифікацію за статтю та стандартизацію опосередкованим методом за віком загиблих. Саме цей метод дозволяє оцінити стандартну похибку отриманих оцінок [7].

Можлива наявність структурних зрушень у класі зовнішніх причин перевірялася за допомогою метода непрямої стандартизації, при цьому за базисний (спонтанний) рівень було прийнято структуру смертності 2008 року (у формі С-8 з 2008 року отруєння алкоголем та іншими отруйними речовинами були відокремлені від «інших причин»).

Проведений аналіз виявив, що за 2009-2016 роки відбу(20,1\%) та новоутворення $(17,2 \%)$, при цьому порівняно Динаміка стандартизованого показника смертності за окремими зовнішніми причинами, на $10^{5}$ нас., Україна, 2008-2016 роки

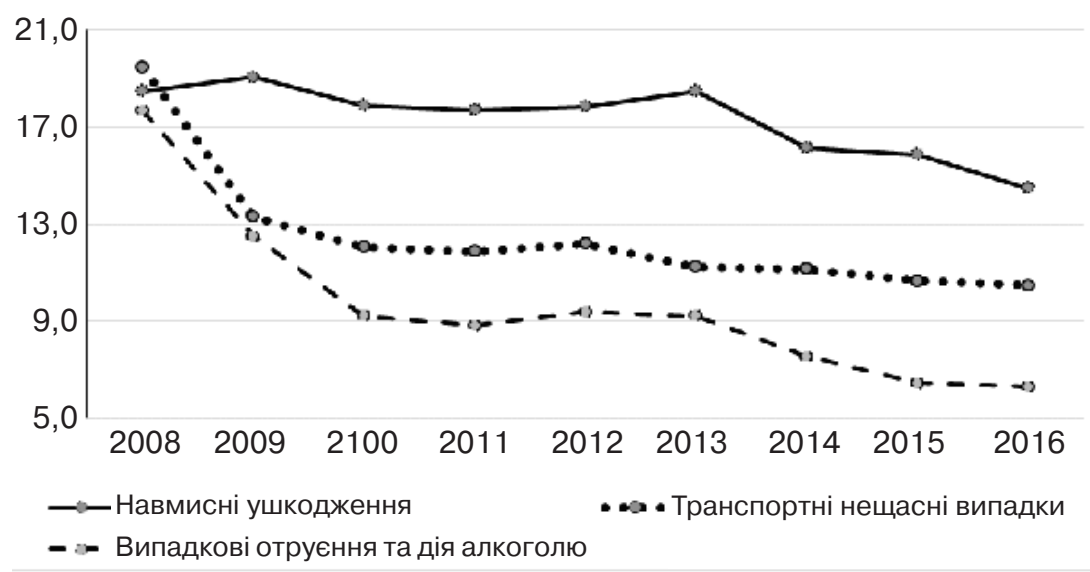

лося значуще збільшення порівняно з 2008 року стандартизованої питомої ваги самогубств у класі зовнішніх причин серед чоловіків на $(37,1 \pm 0,8) \%$ та серед жінок на $(42,2 \pm 1,2) \%$, при цьому виявлено вагоме зменшення внеску смертельних випадкових отруєнь та дії алкоголю, а саме: на $(29,3 \pm 0,7) \%$ та $(36,2 \pm 0,8) \%$ серед чоловіків та жінок відповідно. Також встановлено зменшення питомої ваги смертельних транспортних нещасних випадків серед усього населення, але тільки за рахунок чоловічого населення - на $(6,1 \pm 0,3) \%$.

Фактично серед причин смертності з зовнішніх причин поряд з транспортними випадками особливо виділяють навмисні самоушкодження (X60-Х84), динаміку стандартизованих показників (прямий метод) яких разом 3 транспортними нещасними випадками та випадковими отруєннями і дією алкоголю наведено на рисунку 3.

Хоча протягом зазначеного періоду спостереження рівень смертності серед усього населення (з урахуванням статево-вікової структури) зменшувався, темпи змін оцінено як від'ємні за усіма нозологіями, але смертність, що зумовлена транспортними пригодами, зменшилася в 1,9 рази, через випадкові отруєння та дію алкоголю - у 2,8 рази, а за навмисними ушкодженнями - лише в 1,3 рази.

2014 року зменшення показника смертності за суїцидами та випадковими отруєннями, переважно пов'язаними з дією алкоголю, порівняно з 2013 роком частково пояснюється тим, що достовірних даних життєвої статистики по тимчасово окупованим територіям та зоні проведення АТО немає. Ці території виключено з аналізу, а їхній внесок був суттєвим. Але протягом 2014 року збільшилася смертність, пов'язана $з$ проведенням АТО та погіршенням криміногенної ситуації. Більш того, смертність через ведення 
бойових дій держави повністю ще не врахована.

Для виявлення територіальних особливостей 3 метою проведення ефективних профілактичних заходів зі зменшення смертності з причин, що не є наслідком захворювань, проведено ранжування областей України за стандартизованим відносним ризиком смерті (опосередкований метод стандартизації [8]).

Метод опосередкованої стандартизації дозволяє представити стандартизований за непрямим методом показник смертності як співвідношення кількості випадків смерті, що зареєстровані, та очікуваною за базисним рівнем кількістю їх у досліджуваному контингенті населення. Цей метод переважно застосовується при малому числі смертей і дозволяє побудувати не тільки точкову оцінку, а й інтервальну оцінку (наприклад, 95\% довірчий інтервал) їхнього надлишку [9]. Як спонтанний рівень досліджуваної причини смерті розглядався відповідний показник по Україні за виключенням тимчасово окупованої території Автономної Республіки Крим, м. Севастополя і територій Донецької та Луганської областей (інакше здійснення розрахунків $\epsilon$ некоректним у зв язку з відсутністю інформації по частині тимчасово окупованих територій). Більш того, для запобігання подвійного рахунку порівнювалася окрема область та залучена до дослідження територія держави за виключенням цієї області.

Протягом 2015-2016 років надлишок смертей з зовнішніх причин виявлено серед населення 15 областей держави (рис. 4) загальною кількістю 6805 осіб. При цьому найбільше значення відносного ризику смерті було у населення Херсонської $(1,35$; 95\% ДІ: 1,29-1,40), Житомирської (1,34; 95\% ДІ: 1,29$1,39)$ та Кіровоградської (1,30; 95\% ДІ: 1,25-1,36) областей.

За цей період надлишок кількості смертей через навмисні самоушкодження (2864 особи) встановлено серед населення 14 областей держави. Перші три рангові місця за значенням відносного ризику належать Херсонській $(1,63 ; 95 \%$ ДІ: 1,50$1,76)$, Кіровоградській $(1,60$; 95\% ДІ: 1,47-1,74) та Чернігівській (1,47; 95\% ДІ: 1,35$1,59)$ областям.

Найліпша ситуація за рівнем суїцидів склалася серед населення Львівської $(0,32$; 95\% ДІ: 0,29-0,36) та Харківської $(0,52$; 95\% ДІ: 0,48$0,57)$ областей та у м. Києві (0,30; 95\% ДІ: 0,26-0,33). Кількість самогубств за фактом виявилася меншою, ніж очікувалося.

Додаткові демографічні втрати на досліджуваних територіях держави через випадкове отруєння та дію алкоголю і транспортні нещасні випадки відповідно склали 1507 і 947 осіб. Більш ніж удвічі, ніж очікувалося, зафіксовано випадків смерті переважно через

вживання сурогатного алкоголю серед населення Кіровоградської $(2,67 ; 95 \%$ ДІ: 2,40-2,94), Херсонської (2,16;95\% ДІ: 1,93-2,40) та Хмельницької (2,05; 95\% ДІ: 1,84-2,26) областей.

Як свідчить проведений аналіз, найнебезпечніша ситуація з транспортними нещасними випадками спостерігалася у Київській області, де стандартизований відносний ризик 1,81 (95\% ДІ: 1,68-1,94), а надлишкова смертність становила $81 \%$ (68-94\%). Найбільш благополучним виявився м. Київ (0,70; 95\% ДІ: 0,64-

Рисунок 4

Ранжування областей держави за відносним ризиком смерті з зовнішніх причин та навмисних самоушкоджень, 2015-2016 роки

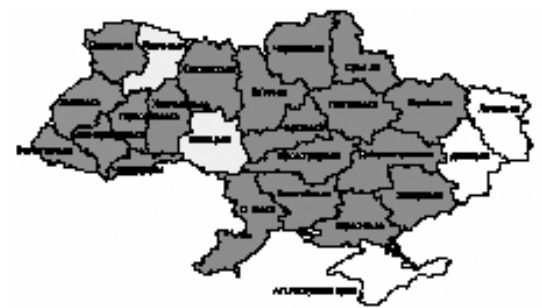

$\checkmark$ зовнішні причини

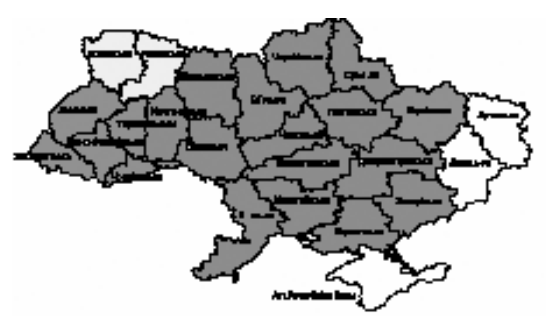

$\checkmark$ навмисні самоушкодження
Ризик нижчий, ніж по іншим територіям країни

Відносний ризик статистично не відрізняється від одиниці

Ризик вищий, ніж по іншим територіям країни

Ранжування областей держави за відносним ризиком Рисунок 5

смерті, через транспортні нещасні випадки, випадкові отруєння та дію алкоголю, 2015-2016 роки
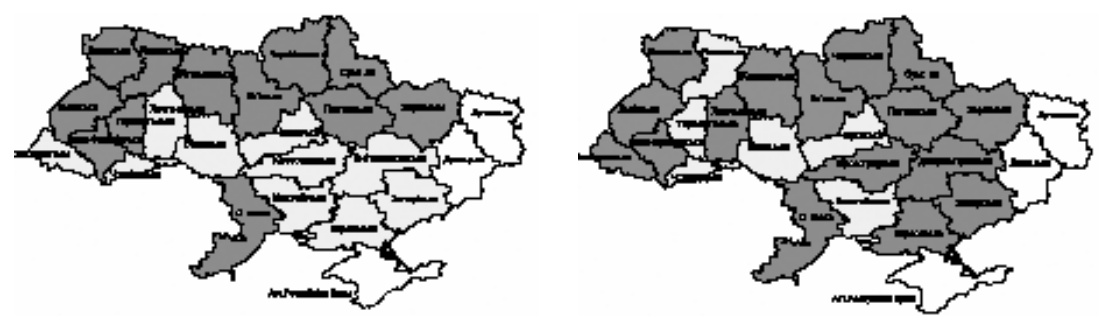

транспортні нещасні випадки

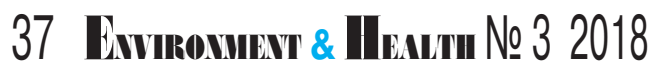

Ризик нижчий, ніж по іншим територіям країніи

Відносний ризик статистично не відрізняється від одиниці

Ризик вищий, ніж по іншим територіям країни 
статистики за 2015-2016 роки щодо національних рахунків середньозваженої облікової ставки НБУ [13], за якою обчислюється норма дисконтування, та коротких таблиць смертності ВСЖ $Ж_{\text {Ам }}$, 2015-2016 оцінюється на рівні 2,1 млн. грн.

Враховуючи це, можна оцінити за допомогою лінійної пропорційної моделі (основа: соціально-економічна концепція [14]) упущену (недоотриману) вигоду держави від надлишкового рівня смертності через усі зовнішні причини, у тому числі через транспортні нещасні випадки, навмисні самоушкодження, отруєння та дію алкоголю порівняно зі спонтанним.

Результати проведених розрахунків наведені у таблиці 2.

Таким чином, урахування досвіду найбільш благополучних областей при плануванні та проведенні профілактичних заходів, навіть без зміни законодавства, дозволило б зберегти життя від 5 до 8 тисяч осіб, які загинули через зовнішні причини протягом двох останніх років спостереження, а цього б не відбулося у випадку значущого зниження відносного ризику смерті серед населення небезпечних у цьому відношенні областей до одиниці та менше. Потенційна соціально-економічна вигода держави склала б від 11 до 17 млрд. грн.

\section{Висновки}

1. В Україні стандартизований показник (європейський стандарт) смертності за зовнішніми причинами протягом останнього десятиріччя перевищував відповідний по- казник у країнах $Є С$ більш ніж удвічі. При збереженні у державі поточних середньорічних темпів змін рівня $Є C$ Україна може досягти не раніше 2030 року.

2. Якщо за класичною структурою смертності зовнішні причини посідають третє рангове місце після хвороб системи кровообігу та новоутворень, то за показником ВРПЖ - друге, при цьому їхній внесок у загальну смертність збільшується у 3,7 рази. Останнє зумовлене тим, що середній вік померлих через зовнішні причини в 1,6 рази менший, ніж у тих, хто помер через хвороби системи кровообігу.

3. Серед усіх зовнішніх причин смерті особливу увагу слід приділити навмисним самоушкодженням, транспортним нещасним випадкам, випадковим отруєнням та дії алкоголю. За показником ВРПЖ їхня питома вага у класі зовнішніх причин смерті становить близько 50\%.

4. При дослідженні структурних зрушень у класі зовнішніх причин виявлено збільшення стандартизованої питомої ваги суїцидів і у жіночого (на $(42,2 \pm 1,2) \%)$, і у чоловічого (на $(37,1 \pm 0,8) \%$ ) населення держави протягом 2009-2016 років.

5. Проведене ранжування областей держави за стандартизованим відносним ризиком визначило території підвищеного ризику за усіма зовнішніми причинами смерті та за окремими нозологіями (транспортні пригоди, самогубства, випадкові отруєння і дія алкоголю). Якби вдалося знизити ризик смерті через ці

Відповідно до статистичних даних Національного комітету

Недоотримана вигода держави за рахунок надлишкової кількості смертей

Таблиця 2 з зовнішніх причин, 2015-2016 роки

\begin{tabular}{|c|c|c|c|c|}
\hline \multirow{3}{*}{ Причина смерті за МКX-10 } & \multicolumn{4}{|c|}{ Показник } \\
\hline & \multicolumn{2}{|c|}{$\begin{array}{c}\text { Оцінка надлишкової } \\
\text { кількості смертей, осіб }\end{array}$} & \multicolumn{2}{|c|}{$\begin{array}{c}\text { Оцінка недоотриманої } \\
\text { вигоди, млн. грн }\end{array}$} \\
\hline & точкова & інтервальна & точкова & інтервальна \\
\hline Транспортні нещасні випадки (V01-V99) & 947 & $552-1308$ & 1988 & $1159-2747$ \\
\hline Випадкове отруєння та дія алкоголю (X45) & 1507 & 1163-1817 & 3165 & $2442-3815$ \\
\hline Навмисне самоушкодження (X60-X84) & 2864 & $2132-3549$ & 6013 & $4478-7452$ \\
\hline Загалом через зовнішні причини смерті: V01-Ү98 & 6805 & $5236-8283$ & 14290 & $10995-17394$ \\
\hline
\end{tabular}


причини до середньодержавного, було б збережено життя близько 7 тисяч осіб, при цьому економічний ефект для держави становив би понад 14 млрд. грн. І це лише за 2015-2016 роки.

\section{ЛІТЕРАТУРА}

1. Травматизм и насилие в Европе. В чем важность этой проблемы и что можно сделать / Всемирная организация здравоохранения, 2006. 26 c. URL : www.euro.who. int/_data/assets/pdf_file/000 8/98405/E87321R.pdf

2. Injury prevention in Europe: From international collaboration to local implementation / World Health Organization, 2010. URL : http://www.euro.who.int/_dat a/assets/pdf_file/0003/1 $\overline{14} 15$ 9/E93567r.pōf

3. Смертность от внешних причин. Здоровье-2020. URL : https://gateway.euro. who.int/ru/indicators/h2020_1 4-mortality-from-externalcauses/

4. Населення України за 2016 рік: демографічний щорічник / Державна служба статистики України. К., 2017. $134 \mathrm{c}$.

5. Орієнтовний календар оприлюднення інформації на 2018 рік. Експрес-випуски. URL : http://www. km.ukrstat. gov.ua/ukr/express/2018/grafi k.htm

6. Blane D., Smith G.D., Bartley M. Social class differences in years of potential life lost: size, trends, and principal causes. British Medical Journal. 1990. № 301.

P. 429-432.

7. Breslow N.E., Day N.E. Statistical Methods in Cancer Research : IARC Scientific Publications No 82. Lyon: International Agency for Research on Cancer, 1987. P. 546-568.

8. Bertell H.R. Extensions of the relative risk concept. Experientia. 1975. Vol. 3. № 1. P. 1-10.

9. Карташова С.С., Тимченко О.И. Совершенствование методов оценки общественного здоровья: применение показателей стандартизированного и кумулятивного риска смерти.
Гигиена и санитария. 2006. № 5. C. 83-86.

10. Канева Т.В., Карташова С.С. Економічний еквівалент оцінки вартості середньостатистичного життя в Україні: методологія, рекомендації. Статистика України. 2014. № 3 (66). С. 31-37.

11. Гербер X. Математика страхования жизни : пер. с англ. М. : Мир, 1995. 156 с.

12. Тарифное руководство по страхованию жизни по Программе накопительного страхования «Линия жизни» Военно-страховой компании / ВСК страховой дом. М. : 2002. 307 c.

13. Облікова ставка НБУ. URL : https://index.minfin. com.ua/ua/banks/nbu/refinance/

14. Быков А.А., Кудрявцев Г.И. Управление риском: оценка натурального и экономического ущерба для здоровья от техногенных воздействий. Проблемы региональной экологии. 1997. № 4. C. 178-191.

\section{REFERENCES}

1. Travmatizm I nasilie $v$ Evrope. V chem vazhnost etoy problemy i chto mozhno sdelat [Injuries and Violence in Europe: why they Matter and what can be done]. WHO, 2006 : 26 p. URL : www.euro.who. int/_data/assets/pdf file/000 8/98405/E87321R.pdf (in Russian).

2. Injury Prevention in Europe: From International Collaboration to Local Implementation / World Health Organization, 2010. URL : http://www.euro.who.int/_dat a/assets/pdf_file/0003/1 $\overline{14} 15$ 9/E93567r.pōf

3. Smertnost ot vneshnikh prichin. Zdorovie-2020.

[Mortality of External Causes. Health-2020]. URL :

https://gateway. euro. who.int/r u/indicators/h2020_14-mortality-from-external-cāuses/

(in Russian).

4. Derzhavna sluzhba statystyky Ukrainy. Naselennia Ukrainy za 2016 rik: demohrafichnyi shchorichnyk [State Statistics Service of Ukraine. Population of Ukraine in 2016: Demographic Year-Book]. Kyiv ; 2017 : 134 p. (in Ukrainian).
5. Opryliudnennia ekspresvypuskiv Derzhstatu u 2018 rotsi [Publication of the Express Issues of the State Statistics Service in 2018]. URL : http://www.km.ukrstat.gov.ua/ ukr/express/2018/grafik.htm (in Ukrainian).

6. Blane D., Smith G.D. and Bartley M. British Medical Journal. 1990 ; 301: 429-432.

7. Breslow N.E. and Day N.E. Statistical Methods in Cancer Research : IARC Scientific Publications № 82. Lyon : International Agency for Research on Cancer; 1987 : 546-568.

8. Bertell H.R. Experientia. $1975 ; 3$ (1) : 1-10.

9. Kartashova S.S. and Timchenko O.I. Gigiena $i$ sanitariia. 2006 ; 5 : 83-86 (in Russian).

10. Kaneva T.V. and

Kartashova S.S. Statystyka Ukrainy. 2014 ; 3 (66) : 31-37 (in Ukrainian).

11. Gerber H.U. Matematika strakhovaniia zhizni [Life Insurance Mathematics]. Moscow : Mir ; 1995 : 156 p. (in Russian).

12. Tarifnoe rukovodstvo po strakhovaniiu zhizni po Programme nakopitelnogo strakhovaniia «Liniia zhizni» Voenno-strakhovoi kompanii [Tariff Guide to Life Insurance under Life Line Insurance Program of the Military Insurance Company]. Moscow ; 2002 : 307 p. (in Russian).

13. Oblikova stavka NBU [NBU Discount Rate]. URL : https://index.minfin.com.ua/ua /banks/nbu/refinance/

(in Ukrainian)

14. Bykov A.A. and

Kudriavtsev G.I. Problemy regionalnoi ekologii. 1997 ; 4 : 178-191 (in Russian).

Надійшло до редакції 14.05.2018 